\title{
Association between Smoking and Risk of Primary Biliary Cholangitis: A Systematic Review and Meta-Analysis
}

\author{
Karn Wijarnpreecha ${ }^{1}$, Monia Werlang ${ }^{1}$, Panadeekarn Panjawatanan ${ }^{2}$, Paul T. Kroner ${ }^{1}$, Omar Y. Mousa ${ }^{3}$, Surakit \\ Pungpapong $^{1}$, Frank J. Lukens ${ }^{1}$, Denise M. Harnois ${ }^{1}$, Patompong Ungprasert ${ }^{4}$
}

\author{
1) Division of \\ Gastroenterology and \\ Hepatology, Mayo Clinic \\ College of Medicine, Mayo \\ Clinic, Jacksonville, Florida, \\ USA \\ 2) Department of Medicine, \\ Bassett Medical Center, \\ Cooperstown, New York, USA \\ 3) Division of \\ Gastroenterology and \\ Hepatology, Mayo Clinic \\ College of Medicine, Mayo \\ Clinic, Rochester, Minnesota, \\ USA \\ 4) Clinical Epidemiology \\ Unit, Department of Research \\ and Development, Faculty \\ of Medicine Siriraj Hospital, \\ Mahidol University, Bangkok, \\ Thailand
}

Address for correspondence: Patompong Ungprasert, MD, MS

2 Wanglang Road, Bangkoknoi, Bangkok, Thailand 10700 p.ungprasert@gmail.com

Received: 03.04.2019 Accepted: 22.05.2019

\section{ABSTRACT}

Background \& Aims: Studies have suggested that smokers may have a higher risk of primary biliary cholangitis (PBC) although the results have been inconsistent. This systematic review and meta-analysis aim to better characterize the risk of $\mathrm{PBC}$ among smokers by identifying all relevant studies and summarizing their results together.

Methods: A comprehensive literature review was conducted using Embase and Pubmed/MEDLINE databases from inception to September 2018 to identify all studies which compared the risk of PBC among current, ever and former smokers to non-smokers. Effect estimates from each study were extracted and combined together using the random-effect, generic inverse variance method of DerSimonian and Laird.

Results: Nine case-control studies with 21,577 participants met the eligibility criteria and were included in the meta-analysis. The risk of $\mathrm{PBC}$ among ever smokers was significantly higher than non-smokers with the pooled odds ratio (OR) of 1.31 (95\% CI, 1.03-1.67; $\left.\mathrm{I}^{2} 89 \%\right)$. Subgroup analysis found that the risk was higher in both former smokers (pooled OR 1.36; 95\% CI, 1.01-1.84; $\mathrm{I}^{2} 75 \%$ ) and current smokers (pooled OR 1.18; $95 \%$ CI, 0.94-1.50; $\mathrm{I}^{2} 79 \%$ ), although the latter did not reach statistical significance. Immunomodulatory and cytotoxic effect of cigarettes were the possible mechanisms behind this increased risk.

Conclusions: A significantly increased risk of $\mathrm{PBC}$ among individuals who ever smoked was observed in this study, adding to the already long list of harmful health consequences of smoking.

Key words: primary biliary cholangitis - biliary cirrhosis - smoking - cigarettes - meta-analysis.

Abbreviations: PBC: primary biliary cholangitis.

\section{INTRODUCTION}

Primary biliary cholangitis (PBC) is a chronic autoimmune cholestatic liver disease characterized by the presence of anti-mitochondrial antibody and destruction of the intrahepatic bile ducts [1]. The reported prevalence of $\mathrm{PBC}$ was approximately 19 to 400 cases per 1,000,000 persons in Western countries $[2,3]$. The exact cause of $\mathrm{PBC}$ is not known but is believed to be a complex interaction between genetic and environmental factors [4, 5]. Interestingly, $\mathrm{PBC}$ is often found in association with certain autoimmune disorders, such as inflammatory bowel disease and autoimmune thyroid disease [4].

Cigarette smoking is one of the leading causes of preventable death worldwide as a result of the increased risk of cardiovascular and pulmonary diseases and malignancy [6, 7]. In fact, even among smokers who have already developed cardiovascular disease, smoking cessation can reduce the risk of mortality by $36 \%$ compared with smokers who continued to smoke [8]. Smoking may also increase the risk of PBC as suggested by multiple epidemiologic studies, although the results were inconsistent [4,9-16]. This systematic review and meta-analysis was conducted with the aim to better characterize the risk of $\mathrm{PBC}$ among smokers by identifying all relevant studies and summarizing their results together.

\section{METHODS}

Information sources and search strategy

A systematic literature search was conducted using the Embase and Pubmed / MEDLINE databases from inception to September 
2018 to identify all original studies that reported the relationship between smoking and PBC. The systematic literature review was independently conducted by three investigators (K.W., P.P., and P.U.) using the search strategy that included the terms for "primary biliary cholangitis", "primary biliary cirrhosis", "smoking" and "cigarettes". A manual search for additional potentially relevant studies using the references of the included studies and selected review articles was also performed. No language limitation was applied. This study was conducted in accordance to the PRISMA (Preferred reporting Items for Systematic Reviews and MetaAnalysis) (see Supplementary TableI). EndNote X7 (Clarivate Analytics, Pennsylvania, United States) was used for study retrieval.

\section{Selection criteria}

Eligible studies must be case-control or cohort studies that compared the risk of PBC among current smokers, ever smokers and former smokers versus non-smokers. Eligible cohort studies must start with recruitment of smokers and non-smokers (without history of PBC at enrollment) and follow them until the occurrence of $\mathrm{PBC}$ or the end of the study. Eligible casecontrol studies must recruit cases with $\mathrm{PBC}$ and controls without $\mathrm{PBC}$ and ask for their smoking status (current, former and never). Eligible studies must provide the effect estimates (odds ratios, $\mathrm{OR}$, relative risks, $\mathrm{RR}$, hazard ratios, $\mathrm{HR}$ or standardized incidence ratio, SIR) with $95 \%$ confidence intervals (CI) or sufficient raw data to calculate those effect estimates. Inclusion was not restricted by study size. When more than one study using the same database / cohort was available, only the study with the most comprehensive data / analyses was included.

Retrieved articles were independently reviewed for their eligibility by the same three investigators. Discrepancy was resolved by conference with all investigators. The NewcastleOttawa quality assessment scale was used to appraise the quality of the included studies in three areas, including identification and recruitment of participants, the comparability between the two groups and the ascertainment of the outcome of interest for the cohort study and the exposure of interest for the casecontrol study [17]. Kappa statistics were used for the evaluation of inter-rater agreement on the Newcastle-Ottawa scale.

\section{Data abstraction}

A structured data collection form was used to extract the following data from each study: title of the study, publication year, name of the first author, calendar year(s) when the study was conducted, country or countries where the study was conducted, number of subjects, demographic data of subjects, methods used to identify and verify diagnosis of $\mathrm{PBC}$ as well as smoking status, adjusted effect estimates with 95\% CI and covariates that were adjusted in the multivariable analysis.

To ensure the accuracy, this data extraction process was independently performed by two investigators (K.W. and P.P.). Case record forms were cross-checked by the senior investigator (P.U.). Any data discrepancy was resolved by referring back to the original articles.

\section{Statistical analysis}

Data analysis was performed using the Review Manager 5.3 software from the Cochrane Collaboration (London,
United Kingdom). Adjusted point estimates for the association between smoking status and PBC from each study were extracted and combined using the generic inverse variance method of DerSimonian and Laird, which assigned the weight of each study in the pooled analysis inversely to its variance [18].

In light of the high likelihood of between study variance because of the difference in background populations, a random-effect model was used. Cochran's Q test and $\mathrm{I}^{2}$ statistic were used to determine the between-study heterogeneity. This $\mathrm{I}^{2}$ statistic quantifies the proportion of total variation across studies, which is due to true heterogeneity rather than chance. A value of $\mathrm{I}^{2}$ of $0-25 \%$ represents insignificant heterogeneity, 26-50\% represents low heterogeneity, 51$75 \%$ represents moderate heterogeneity and more than $75 \%$ represents high heterogeneity [19]. We used a funnel plot and the Egger's regression test for the assessment of the presence of publication bias. We performed Egger's regression test using Comprehensive Meta-analysis 3.0 software (Englewood, New Jersey, United States) [20].

\section{RESULTS}

Two hundred and eighty-three potentially eligible articles were identified using the described search strategy ( 99 articles from Medline and 184 articles from EMBASE). After the exclusion of 98 duplicated articles, 185 articles underwent a title and abstract review. A total of 165 articles were excluded at this stage since they clearly did not fulfill the eligibility criteria based on the type of article, study design, population and measured outcomes, leaving 20 articles for a full-text review. Eight of them were excluded after the full-length review, as they did not report the outcome of interest. Three articles were excluded because they were descriptive studies without comparators. Finally, nine case-control studies [4, 9-16] with 21,577 participants were included in the meta-analysis. The literature review and selection process are demonstrated in Fig. 1. The characteristics and quality assessment of the studies are presented in Table I. It should be noted that the inter-rater agreement for the quality assessment using the NewcastleOttawa scale was high with the kappa statistics of 0.68 .

Risk of primary biliary cholangitis among ever smokers, former smokers and current smokers

Overall, the pooled analysis demonstrated an increased risk of PBC among ever smokers compared with non-smokers with the pooled OR of 1.31 (95\% CI, 1.03-1.67). Statistical heterogeneity was high with $\mathrm{I}^{2}$ of $89 \%$. Subgroup analysis found the increased risk of PBC in both former smokers and current smokers, although a statistical significance was not reached by the latter (pooled OR 1.36; 95\% CI, 1.01-1.84; $\mathrm{I}^{2}$ of $75 \%$ and pooled OR 1.18 ; 95\% CI, $0.94-1.50$; $\mathrm{I}^{2}$ of $79 \%$, respectively). The forest plots of the meta-analyses of the risk of PBC among ever smokers, former smokers and current smokers are shown in Figs. 2, 3 and 4, respectively.

\section{Sensitivity analysis}

To further explore the high between-study heterogeneity of the main analysis of ever smokers versus non-smokers, a 


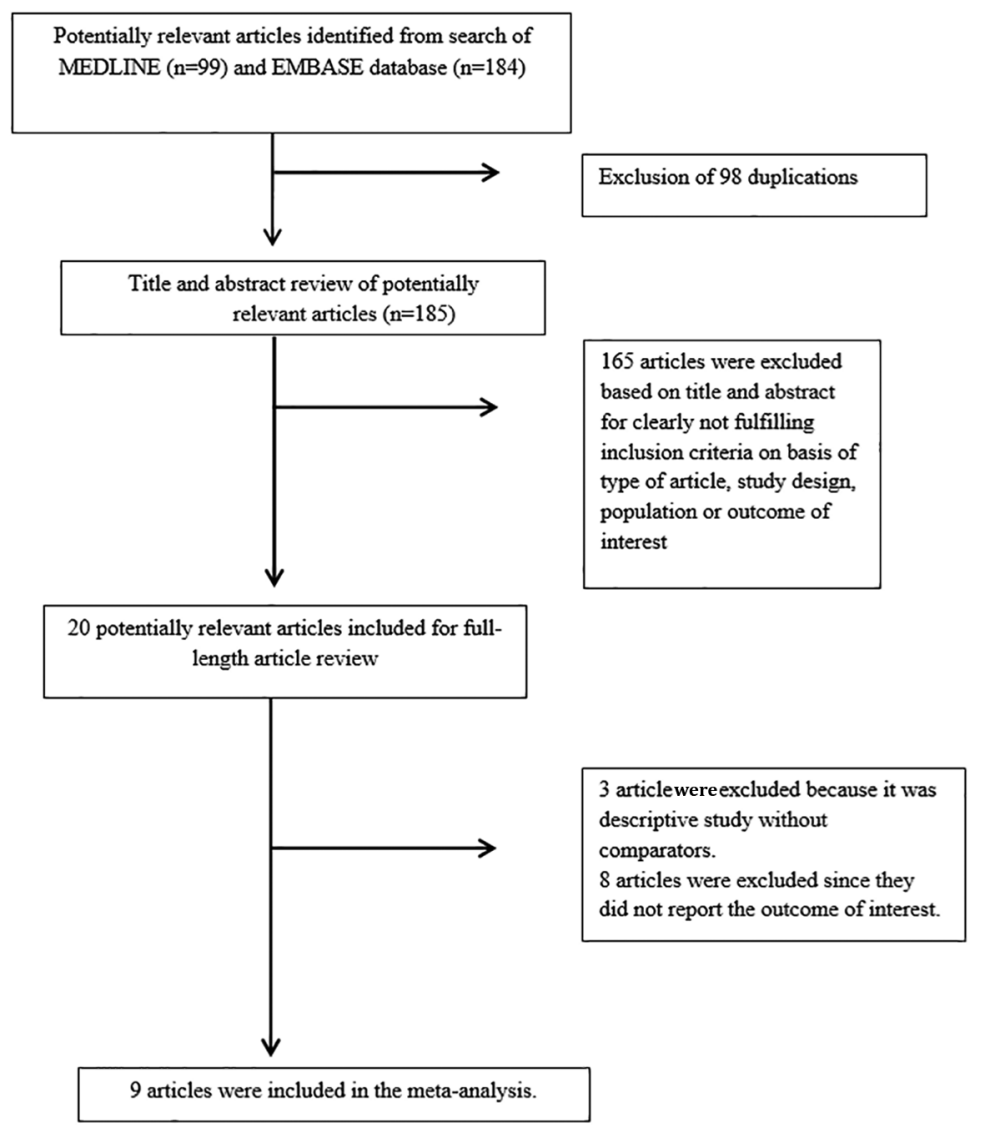

Fig. 1. Literature review process

sensitivity analysis based on quality of the included studies was performed. This sensitivity analysis excluded two studies $[12,16]$ with obvious methodological drawback from the full analysis. The study by Varyani et al. [16] was excluded because it was the only study that diagnosed PBC based on diagnostic codes alone without further case verification which would result in a limited accuracy of case identification. The study by Lammert et al. [12] was excluded because it was the only study that did not match their controls to cases by age and sex. Therefore, it was likely that the result of this study

\begin{tabular}{|c|c|c|c|c|c|}
\hline Study or Subgroup & log[Odds Ratio] & SE & Weight & $\begin{array}{l}\text { Odds Ratio } \\
\text { IV, Random, } 95 \% \mathrm{Cl}\end{array}$ & Year \\
\hline Howel et al. & 0.8755 & 0.275 & $7.8 \%$ & $2.40[1.40,4.11]$ & 2000 \\
\hline Parikh-Patel et al. & 0.7129 & 0.3151 & $6.9 \%$ & $2.04[1.10,3.78]$ & 2001 \\
\hline Gershwin et al. & 0.2642 & 0.0889 & $11.8 \%$ & $1.30[1.09,1.55]$ & 2005 \\
\hline Prince et al. (1) & 0.47 & 0.1468 & $10.7 \%$ & $1.60[1.20,2.13]$ & 2009 \\
\hline Prince et al. (2) & 0.4055 & 0.073 & $12.0 \%$ & $1.50[1.30,1.73]$ & 2010 \\
\hline Corpechot et al. & -0.0265 & 0.1643 & $10.3 \%$ & $0.97[0.71,1.34]$ & 2010 \\
\hline Varyani et al. & -0.3141 & 0.0736 & $12.0 \%$ & $0.73[0.63,0.84]$ & 2012 \\
\hline Mantaka et al. & -0.1797 & 0.2651 & $8.0 \%$ & $0.84[0.50,1.40]$ & 2012 \\
\hline Boonstra et al. & 0.1762 & 0.2071 & $9.3 \%$ & $1.19[0.79,1.79]$ & 2013 \\
\hline Lammert et al. & 0.5309 & 0.1202 & $11.2 \%$ & $1.70[1.34,2.15]$ & 2013 \\
\hline Total $(95 \% \mathrm{Cl})$ & & & $100.0 \%$ & $1.31[1.03,1.67]$ & \\
\hline \multicolumn{6}{|c|}{ Heterogeneity: $\mathrm{Tau}^{2}=0.12 ; \mathrm{Chi}^{2}=80.61, \mathrm{df}=9(\mathrm{P}<0.00001) ; \mathrm{I}^{2}=89 \%$} \\
\hline
\end{tabular}

Odds Ratio

Study or Subgroup log[Odds Ratio] SE Weight IV, Random, $95 \% \mathrm{Cl}$ Year Parikh-Patel et Gershwin et al. Corpechot et al.

Mantaka et al.

Lammert et al.

Boonstra et al.

Total $(95 \% \mathrm{Cl})$ $\begin{array}{lll}0.4814 & 0.0951 & 22.7 \%\end{array}$ $\begin{array}{lll}-0.3121 & 0.1981 \quad 17.6 \%\end{array}$

$\begin{array}{lll}-0.0796 & 0.3847 \quad 9.7 \%\end{array}$

$0.6184 \quad 0.1331 \quad 20.9 \%$

$0.1823 \quad 0.275 \quad 13.9 \%$

$100.0 \%$

$1.62[1.34,1.95] 2005$

$0.73[0.50,1.08] 2010$

$0.92[0.43,1.96] 2012$

$1.86[1.43,2.41] 2013$

$1.20[0.70,2.06] 2013$

Heterogeneity: $\mathrm{Tau}^{2}=0.10 ; \mathrm{Chi}^{2}=20.03, \mathrm{df}=5(\mathrm{P}=0.001) ;\left.\right|^{2}=75 \%$

Test for overall effect: $Z=2.00(P=0.05)$

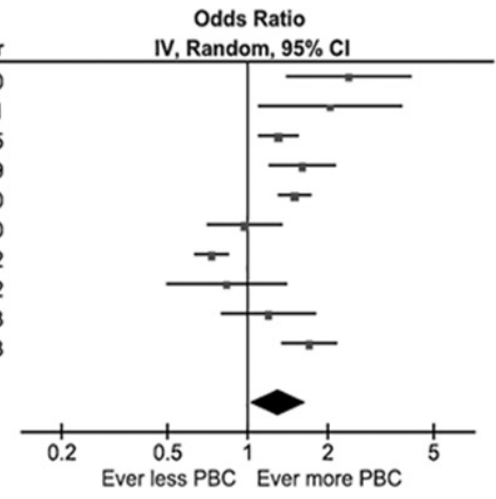

Fig. 2. Forest plot of the metaanalysis evaluating the risk of primary biliary cholangitis among ever smokers compared with non-smokers.

Fig. 3. Forest plot of the metaanalysis evaluating the risk of primary biliary cholangitis among former smokers compared with non-smokers. 
Table I. Main characteristics of the studies included in this meta-analysis

\begin{tabular}{|c|c|c|c|c|c|}
\hline Study & Howel et al. [11] & Parikh-Patel et al. [14] & Gershwin et al. [4] & Prince et al. [15] & Corpechot et al. [10] \\
\hline Country/Year & $\mathrm{UK} / 2000$ & USA/2001 & USA/2005 & $\mathrm{UK} / 2009$ & France/2010 \\
\hline $\begin{array}{l}\text { Total number } \\
\text { of participants }\end{array}$ & $\begin{array}{l}322 \text { ( } 100 \text { patients with } \mathrm{PBC} \\
\text { and } 222 \text { subjects without } \\
\mathrm{PBC})\end{array}$ & $\begin{array}{l}342 \text { ( } 201 \text { patients with } \\
\text { PBC and } 141 \text { subjects } \\
\text { without } \mathrm{PBC})\end{array}$ & $\begin{array}{l}2,073 \text { ( } 1,032 \text { patients } \\
\text { with } \mathrm{PBC} \text { and } 1,041 \\
\text { subjects without } \mathrm{PBC})\end{array}$ & $\begin{array}{l}5,014 \text { ( } 2,576 \text { patients } \\
\text { with } \mathrm{PBC} \text { and } 2,438 \\
\text { subjects without } \mathrm{PBC})\end{array}$ & $\begin{array}{l}731 \text { (222 patients with } \\
\text { PBC and } 509 \text { subjects } \\
\text { without } \mathrm{PBC})\end{array}$ \\
\hline Participants & $\begin{array}{l}\text { Cases: patients with PBC } \\
\text { aged } 18 \text { years and older } \\
\text { who were first given the } \\
\text { diagnosis between January } \\
1,1993 \text { and October } 31 \text {, } \\
1995 \text { and identified from a } \\
\text { population-based register } \\
\text { that covered } 6 \text { districts in } \\
\text { the UK. } \\
\text { Controls: individuals } \\
\text { without PBC identified } \\
\text { from the Family health } \\
\text { service authority registers } \\
\text { of the same regions with sex } \\
\text { and age-matched to cases }\end{array}$ & $\begin{array}{l}\text { Cases: Cases were } \\
\text { patients with PBC } \\
\text { identified from internet } \\
\text { support group for PBC } \\
\text { Controls: individuals } \\
\text { without PBC who } \\
\text { were friends of cases } \\
\text { with PBC (names and } \\
\text { addresses of controls } \\
\text { were provided to } \\
\text { investigators by cases) } \\
\text { with sex and age- } \\
\text { matched to cases }\end{array}$ & $\begin{array}{l}\text { Cases: patients with PBC } \\
\text { seen by hepatologists } \\
\text { from one of the study } \\
23 \text { centers across the US } \\
\text { between November } 1999 \\
\text { and June } 2004 \text {. } \\
\text { Controls: individuals } \\
\text { without PBC selected } \\
\text { by random-digit-dialing } \\
\text { method with sex, age, } \\
\text { ethnicity and geographic } \\
\text { area-matched to cases }\end{array}$ & $\begin{array}{l}\text { Cases: patients with } \\
\text { PBC were identified } \\
\text { from } 2 \text { sources (1) the } \\
\text { survey of consultant } \\
\text { gastroenterologists } \\
\text { and hepatologists in } \\
\text { the northeast England } \\
\text { from } 1997 \text { to } 2003 \text { and } \\
\text { (2) member list of the } \\
\text { UK PBC foundation } \\
\text { (cases with residency in } \\
\text { the northeast area were } \\
\text { excluded to avoid double } \\
\text { counting) } \\
\text { Controls: individuals } \\
\text { without PBC randomly } \\
\text { selected from electoral } \\
\text { roll datasets with sex and } \\
\text { age-matched to cases }\end{array}$ & $\begin{array}{l}\text { Cases: patients with } \\
\text { PBC were identified } \\
\text { from the database } \\
\text { of the Saint-Antoine } \\
\text { hospital, Paris, France. } \\
\text { Controls: individuals } \\
\text { without PBC } \\
\text { randomly selected } \\
\text { from the Ipsos access } \\
\text { panels with sex, age, } \\
\text { and geographic area- } \\
\text { matched to cases }\end{array}$ \\
\hline $\begin{array}{l}\text { Determination } \\
\text { of smoking } \\
\text { status }\end{array}$ & $\begin{array}{l}\text { self-reported using health } \\
\text { questionnaire }\end{array}$ & $\begin{array}{l}\text { self-reported using } \\
\text { health questionnaire }\end{array}$ & $\begin{array}{l}\text { self-reported using } \\
\text { health questionnaire }\end{array}$ & $\begin{array}{l}\text { self-reported using } \\
\text { health questionnaire }\end{array}$ & $\begin{array}{l}\text { self-reported using } \\
\text { health questionnaire }\end{array}$ \\
\hline $\begin{array}{l}\text { Diagnosis of } \\
\text { PBC }\end{array}$ & $\begin{array}{l}\text { At least } 2 \text { of the following } \\
\text { criteria: (1) presence of } \\
\text { AMA ( } \geq 1: 40),(2) \text { abnormal } \\
\text { LFT (bilirubin, AST, and } \\
\text { ALP), (3) compatible liver } \\
\text { histology. }\end{array}$ & $\begin{array}{l}\text { self-reported; half } \\
\text { of them were also } \\
\text { verified by the presence } \\
\text { of AMA plus either } \\
\text { cholestatic pattern of } \\
\text { serum biochemical } \\
\text { tests or compatible liver } \\
\text { histology }\end{array}$ & $\begin{array}{l}\text { Presence of AMA plus } \\
\text { either cholestatic pattern } \\
\text { of serum biochemical } \\
\text { tests or compatible liver } \\
\text { histology. } \\
\text { In the case of negative } \\
\text { AMA, diagnosis can } \\
\text { still be made with } \\
\text { positive ANA or ASMA } \\
\text { and presence of both } \\
\text { cholestatic pattern } \\
\text { biochemical tests } \\
\text { and compatible liver } \\
\text { histology. }\end{array}$ & $\begin{array}{l}\text { At least } 2 \text { of the } \\
\text { following criteria: }(1) \\
\text { persistently cholestatic } \\
\text { LFT over } 3 \text { months, } \\
\text { (2) presence of AMA } \\
\text { ( } \geq 1: 40 \text { or greater twice } \\
\text { or more), (3) compatible } \\
\text { liver histology }\end{array}$ & $\begin{array}{l}\text { Presence of } \\
\text { biochemical evidence } \\
\text { of prolonged } \\
\text { cholestasis, presence } \\
\text { of AMA, and } \\
\text { compatible liver } \\
\text { histology }\end{array}$ \\
\hline $\begin{array}{l}\text { Percentage of } \\
\text { females }\end{array}$ & $\begin{array}{l}\text { Cases: N/A } \\
\text { Controls: N/A }\end{array}$ & $\begin{array}{l}\text { Controls: N/A } \\
\text { Cases: N/A }\end{array}$ & $\begin{array}{l}\text { Cases: } 93 \\
\text { Controls: } 92\end{array}$ & $\begin{array}{l}\text { Cases: } 93 \\
\text { Controls: N/A }\end{array}$ & $\begin{array}{l}\text { Cases: } 89 \\
\text { Controls: } 85\end{array}$ \\
\hline $\begin{array}{l}\text { Average age of } \\
\text { participants in } \\
\text { years }\end{array}$ & $\begin{array}{l}\text { Cases: N/A } \\
\text { Controls: N/A }\end{array}$ & $\begin{array}{l}\text { Cases: } 53 \\
\text { Controls: } 54\end{array}$ & $\begin{array}{l}\text { Cases: } 58 \\
\text { Controls: } 58\end{array}$ & $\begin{array}{l}\text { Cases: N/A } \\
\text { Controls: N/A }\end{array}$ & $\begin{array}{l}\text { Cases: } 60 \\
\text { Controls: } 59\end{array}$ \\
\hline $\begin{array}{l}\text { Confounder } \\
\text { adjusted in } \\
\text { multivariate } \\
\text { analysis }\end{array}$ & None & $\begin{array}{l}\text { Other autoimmune } \\
\text { disease, history of } \\
\text { tonsillectomy and } \\
\text { history of abdominal } \\
\text { surgery }\end{array}$ & None & $\begin{array}{l}\text { Age, alcohol intake, hair } \\
\text { dye, appendectomy, } \\
\text { tonsillectomy, thyroid } \\
\text { disease, celiac disease, } \\
\text { UTI, shingles and } \\
\text { obstetric pruritus }\end{array}$ & None \\
\hline $\begin{array}{l}\text { Quality } \\
\text { assessment } \\
\text { (Newcastle- } \\
\text { Ottawa scale) }\end{array}$ & $\begin{array}{l}\text { Selection: } 4 \\
\text { Comparability: } 1 \\
\text { Outcome: } 2\end{array}$ & $\begin{array}{l}\text { Selection: } 4 \\
\text { Comparability: } 1 \\
\text { Outcome: } 2\end{array}$ & $\begin{array}{l}\text { Selection: } 4 \\
\text { Comparability: } 2 \\
\text { Outcome: } 3\end{array}$ & $\begin{array}{l}\text { Selection: } 3 \\
\text { Comparability: } 1 \\
\text { Outcome: } 2\end{array}$ & $\begin{array}{l}\text { Selection: } 4 \\
\text { Comparability: } 2 \\
\text { Outcome: } 2\end{array}$ \\
\hline
\end{tabular}

\begin{tabular}{|c|c|c|c|c|}
\hline Study & Varyani et al. [16] & Mantaka et al. [13] & Lammert et al. [12] & Boonstra et al. [9] \\
\hline Country & $\mathrm{UK} / 2012$ & Greece/2012 & USA/2013 & The Netherlands/2013 \\
\hline $\begin{array}{l}\text { Total number of } \\
\text { participants }\end{array}$ & $\begin{array}{l}11,105 \text { ( } 1,009 \text { patients with } \\
\text { PBC and } 10,096 \text { subjects } \\
\text { without } \mathrm{PBC})\end{array}$ & $\begin{array}{l}260 \text { ( } 111 \text { patients with } \\
\text { PBC and } 149 \text { subjects } \\
\text { without } \mathrm{PBC} \text { ) }\end{array}$ & $\begin{array}{l}\text { 1,138 (522 patients with } \mathrm{PBC} \\
\text { and } 616 \text { patients without } \mathrm{PBC} \text { ) }\end{array}$ & $\begin{array}{l}592 \text { ( } 464 \text { patients with } \mathrm{PBC} \text { and } \\
128 \text { patients without } \mathrm{PBC} \text { ) }\end{array}$ \\
\hline
\end{tabular}


Table I (continued)

\begin{tabular}{|c|c|c|c|c|}
\hline Participants & $\begin{array}{l}\text { Cases: patients with PBC } \\
\text { identified from the GPRD } \\
\text { database which included } \\
\text { over } 50 \text { million patient years } \\
\text { of data from primary care } \\
\text { physicians across the UK } \\
\text { from } 1987 \text { to } 2008 \\
\text { Controls: individuals without } \\
\text { PBC randomly selected from } \\
\text { the same database with sex } \\
\text { and age-matched to cases }\end{array}$ & $\begin{array}{l}\text { Cases: patients with PBC } \\
\text { seen at the Department } \\
\text { of Gastroenterology } \\
\text { and Hepatology of the } \\
\text { University Hospital of } \\
\text { Heraklion, Crete Greece, } \\
\text { from March to October, } \\
2007 \\
\text { Controls: individuals } \\
\text { without PBC who were } \\
\text { recruited from the same } \\
\text { hospital with sex, age } \\
\text { and residence-matched } \\
\text { to cases }\end{array}$ & $\begin{array}{l}\text { Cases: patients with PBC } \\
\text { identified from the MCPGE } \\
\text { Registry which included PBC } \\
\text { patients who followed at Mayo } \\
\text { Clinic and other hospitals across } \\
\text { the US } \\
\text { Controls: individuals without } \\
\text { PBC who were recruited from } \\
\text { general internal medicine clinic } \\
\text { of the Mayo Clinic }\end{array}$ & $\begin{array}{l}\text { Cases: patients with PBC } \\
\text { identified from the databases } \\
\text { of } 44 \text { hospitals which covered } \\
50 \% \text { of the population of the } \\
\text { Netherlands from } 2008 \text { to } 2011 \\
\text { Controls: individuals without } \\
\text { PBC who were recruited } \\
\text { from outpatient clinic of } 4 \\
\text { participating hospitals with sex } \\
\text { and age-matched to cases }\end{array}$ \\
\hline $\begin{array}{l}\text { Determination of } \\
\text { smoking status }\end{array}$ & retrieved from the database & $\begin{array}{l}\text { self-reported using direct } \\
\text { interview }\end{array}$ & $\begin{array}{l}\text { self-reported using health } \\
\text { questionnaire }\end{array}$ & $\begin{array}{l}\text { self-reported using health } \\
\text { questionnaire }\end{array}$ \\
\hline Diagnosis of PBC & $\begin{array}{l}\text { Presence of diagnostic codes } \\
\text { of PBC in the database }\end{array}$ & $\begin{array}{l}\text { Compatible clinical } \\
\text { presentation, liver } \\
\text { histology and biochemical } \\
\text { parameters }\end{array}$ & $\begin{array}{l}\text { Biochemical cholestasis for } \\
\text { more than } 6 \text { months and } \\
\text { compatible liver histology with } \\
\text { or without the presence of AMA }\end{array}$ & $\begin{array}{l}\text { Combination of compatible } \\
\text { clinical presentation, elevation } \\
\text { of liver ALP for at least } 6 \\
\text { months and presence of AMA } \\
(\geq 1: 40)\end{array}$ \\
\hline Percentage of females & $\begin{array}{l}\text { Cases: } 88 \\
\text { Controls: } 88\end{array}$ & $\begin{array}{l}\text { Cases: } 85 \\
\text { Controls: } 85\end{array}$ & $\begin{array}{l}\text { Cases: } 91 \\
\text { Controls: } 75\end{array}$ & $\begin{array}{l}\text { Cases: } 90 \\
\text { Controls: } 84\end{array}$ \\
\hline $\begin{array}{l}\text { Average age of } \\
\text { participants in years }\end{array}$ & $\begin{array}{l}\text { Cases: } 63 \\
\text { Controls: } 63\end{array}$ & Cases: 65 Controls: 65 & $\begin{array}{l}\text { Cases: N/A } \\
\text { Controls: N/A }\end{array}$ & $\begin{array}{l}\text { Cases: } 63 \\
\text { Controls: } 61\end{array}$ \\
\hline $\begin{array}{l}\text { Confounder adjusted } \\
\text { in multivariate } \\
\text { analysis }\end{array}$ & None & None & None & None \\
\hline $\begin{array}{l}\text { Quality assessment } \\
\text { (Newcastle-Ottawa } \\
\text { scale) }\end{array}$ & $\begin{array}{l}\text { Selection: } 4 \\
\text { Comparability: } 1 \\
\text { Outcome: } 2\end{array}$ & $\begin{array}{l}\text { Selection: } 3 \\
\text { Comparability: } 2 \\
\text { Outcome: } 3\end{array}$ & $\begin{array}{l}\text { Selection: } 3 \\
\text { Comparability: } 1 \\
\text { Outcome: } 2\end{array}$ & $\begin{array}{l}\text { Selection: } 4 \\
\text { Comparability: } 1 \\
\text { Outcome: } 2\end{array}$ \\
\hline
\end{tabular}

Abbreviations: ALP: alkaline phosphatase; AMA: antimitochondrial antibody; ANA: antinuclear antibody; ASMA; anti-smooth muscle antibody, AST: aspartate transaminase; GGT: gamma glutamyltranspeptidase; GPRD: the United Kingdom General Practice Research Database; LFT: liver function test; MCPGE: Mayo Clinic PBC Genetic Epidemiology; PBC: primary biliary cholangitis; UTI: urinary tract infection.

\begin{tabular}{|c|c|c|c|c|c|}
\hline Study or Subgroup & log[Odds Ratio] & SE & Weight & $\begin{array}{c}\text { Odds Ratio } \\
\text { IV, Random, } 95 \% \mathrm{Cl}\end{array}$ & Year \\
\hline Parikh-Patel et al. & 0.7398 & 0.3232 & $7.9 \%$ & $2.10[1.11,3.95]$ & 2001 \\
\hline Gershwin et al. & -0.454 & 0.1428 & $14.6 \%$ & $0.64[0.48,0.84]$ & 2005 \\
\hline Prince et al. (1) & 0.3646 & 0.1103 & $16.0 \%$ & $1.44[1.16,1.79]$ & 2009 \\
\hline Corpechot et al. & 0.2267 & 0.2171 & $11.5 \%$ & $1.25[0.82,1.92]$ & 2010 \\
\hline Prince et al. (2) & 0.3365 & 0.0538 & $17.8 \%$ & $1.40[1.26,1.56]$ & 2010 \\
\hline Mantaka et al. & -0.2385 & 0.313 & $8.2 \%$ & $0.79[0.43,1.45]$ & 2012 \\
\hline Lammert et al. & 0.3207 & 0.1816 & $13.0 \%$ & $1.38[0.97,1.97]$ & 2013 \\
\hline Boonstra et al. & 0.0953 & 0.2306 & $11.0 \%$ & $1.10[0.70,1.73]$ & 2013 \\
\hline Total $(95 \% \mathrm{Cl})$ & & & $100.0 \%$ & $1.18[0.94,1.50]$ & \\
\hline \multicolumn{6}{|c|}{ Heterogeneity: $\mathrm{Tau}^{2}=0.08 ; \mathrm{Chi}^{2}=33.30, \mathrm{df}=7(\mathrm{P}<0.0001) ; \mathrm{I}^{2}=79 \%$} \\
\hline Test for overall effect & $=1.41(P=0.16)$ & & & & \\
\hline
\end{tabular}

was confounded by difference in baseline demographic data. Exclusion of these two studies from the full analysis did not significantly alter the pooled result (pooled OR $1.37 ; 95 \%$ CI, $1.16-1.62)$ and decreased between-study heterogeneity to moderate level ( $\left.\mathrm{I}^{2} 59 \%\right)$.

\section{Evaluation for publication bias}

The meta-analysis of the risk of $\mathrm{PBC}$ among ever smokers was used for the evaluation for publication bias as it was the meta-analysis with the highest number of included studies. The graph was symmetric and was not suggestive of publication bias (Fig. 5). In addition, publication bias was not detected by Egger's regression test with p-value of 0.44 .

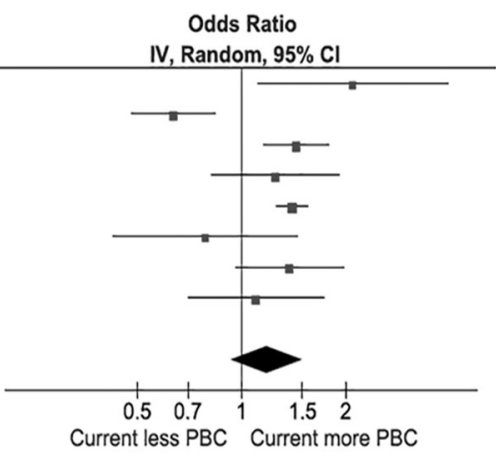

Fig. 4. Forest plot of the metaanalysis evaluating the risk of primary biliary cholangitis among current smokers compared with non-smokers.

\section{DISCUSSION}

The current study is the first systematic review and metaanalysis that comprehensively investigated the relationship between PBC and smoking and found an approximately $30 \%$ increased risk of PBC among individuals who ever smoked. There are some plausible explanations for this observation.

First, cigarettes contain multiple cytotoxic and antigenic components that have detrimental effects on human body [21]. In fact, there is a report of a cluster of cases of PBC near a toxic waste site that produced chlorinated hydrocarbonscontaminated air. These chlorinated hydrocarbons, such as benzene, are also found in cigarettes [22]. 


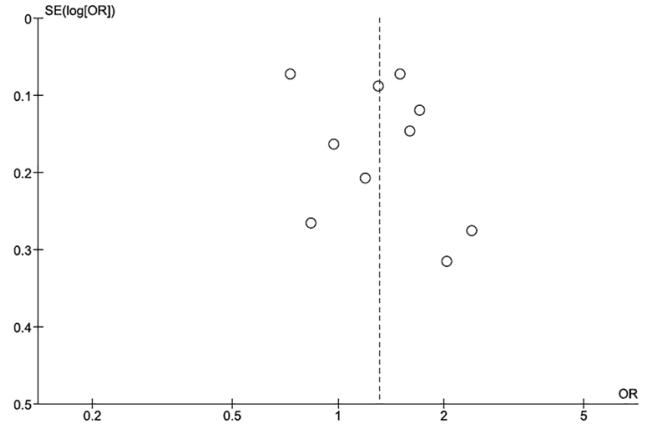

Fig. 5. Funnel plot of the meta-analysis evaluating the risk of primary biliary cholangitis among ever smokers compared with non-smokers.

Second, smoking is known to increase pro-inflammatory interleukins (such as IL-1, IL-6 and IL-8) and tumor necrosis factor alpha, which could disrupt the homeostasis of T cells, resulting in abnormal Thl adaptive immune response [23-26]. This may have an implication in the pathogenesis of PBC, as Th1 cells are the predominant type of lymphoid aggregates seen in the liver of patients with this disease [27, 28].

It should be noted that subgroup analysis of this systematic review and meta-analysis found that the significantly increased risk of $\mathrm{PBC}$ was observed in former smokers but not in current smokers. It is difficult to find a biological mechanism to explain as to why smoking cessation would heighten the risk. The more likely explanation is that smokers who develop serious health consequences are more likely to quit smoking $[29,30]$, resulting in a lower number of current smokers and higher number of former smokers among cases with PBC.

Although the quality of the studies included in the current analysis was high as reflected by the high Newcastle-Ottawa scores and the literature review process was comprehensive, there are some limitations that should be acknowledged.

First, statistical heterogeneity was high in the meta-analysis. We believe that variation in quality of the included studies was one of the factors for the high between-study heterogeneity as sensitivity analysis excluding studies with obvious methodological drawback can reduce the heterogeneity to a moderate level. Second, all of the included studies were conducted in Western countries. Therefore, generalizability of the results to other populations is limited. Third, most studies included in this meta-analysis did not adjust their effect estimates for potential confounders. Therefore, it is also possible that the observed relationship is not causal and is a function of confounding effect.

\section{CONCLUSION}

The current study found a significantly increased risk of PBC among individuals who ever smoked, adding to the already long list of potential harmful health consequences of smoking. Conflict of interest: None to declare.

Authors' contributions: K.W.: study concept and design, acquisition and analysis of data and drafting of the manuscript. M.W.: study concept and design, acquisition and analysis of data, and critical revision of the manuscript. P.P.: acquisition of data, analysis, of data and drafting manuscript. P.T.K., O.M.Y.: interpretation of data and critical revision of the manuscript. S.P., F.L.: study concept, critical revision of the manuscript, and study supervision. D.M.H., P.U. study concept and design, interpretation of data, drafting of the manuscript, critical revision of the manuscript, and study supervision.

Acknowledgement: We thank Melissa Scribani, a professional statistician at Bassett Medical Center in Cooperstown, New York, for her assistance with the review of statistical techniques used in this manuscript.

Supplementary material: To access the supplementary material visit the online version of the $J$ Gastrointestin Liver Dis at http://dx.doi. org/10.15403/jgld-181

\section{REFERENCE}

1. European Association for the Study of the Liver. EASL Clinical Practice Guidelines: The diagnosis and management of patients with primary biliary cholangitis. J Hepatol 2017;67:145-172. doi:10.1016/j. jhep.2017.03.022

2. Kim WR, Lindor KD, Locke GR, 3rd, et al. Epidemiology and natural history of primary biliary cirrhosis in a US community. Gastroenterology 2000;119:1631-1636. doi:10.1053/gast.2000.20197

3. Sood S, Gow PJ, Christie JM, Angus PW. Epidemiology of primary biliary cirrhosis in Victoria, Australia: high prevalence in migrant populations. Gastroenterology 2004;127:470-475. doi:10.1053/j. gastro.2004.04.064

4. Gershwin ME, Selmi C, Worman HJ, et al. Risk factors and comorbidities in primary biliary cirrhosis: a controlled interview-based study of 1032 patients. Hepatology 2005;42:1194-1202. doi:10.1002/hep.20907

5. Jones DE. Pathogenesis of primary biliary cirrhosis. J Hepatol 2003;39:639-648. doi:10.1016/S0168-8278(03)00270-8

6. Centers for Disease Control and Prevention (CDC). Smokingattributable mortality, years of potential life lost, and productivity losses--United States, 2000-2004. MMWR Morb Mortal Wkly Rep 2008;57:1226-1228.

7. Centers for Disease Control and Prevention (CDC). Cigarette smoking among adults and trends in smoking cessation - United States, 2008. MMWR Morb Mortal Wkly Rep 2009;58:1227-1232.

8. Critchley JA, Capewell S. Mortality risk reduction associated with smoking cessation in patients with coronary heart disease: a systematic review. JAMA 2003;290:86-97. doi:10.1001/jama.290.1.86

9. Boonstra K, Kunst AE, Stadhouders PH, et al. Rising incidence and prevalence of primary biliary cirrhosis: a large population-based study. Liver Int 2014;34:e31-e38. doi:10.1111/liv.12434

10. Corpechot C, Chretien Y, Chazouilleres O, Poupon R. Demographic, lifestyle, medical and familial factors associated with primary biliary cirrhosis. J Hepatol 2010;53:162-169. doi:10.1016/j.jhep.2010.02.019

11. Howel D, Fischbacher CM, Bhopal RS, Gray J, Metcalf JV, James OF. An exploratory population-based case-control study of primary biliary cirrhosis. Hepatology 2000;31:1055-1060. doi:10.1053/he.2000.7050

12. Lammert C, Nguyen DL, Juran BD, et al. Questionnaire based assessment of risk factors for primary biliary cirrhosis. Dig Liver Dis 2013;45:589-594. doi:10.1016/j.dld.2013.01.028

13. Mantaka A, Koulentaki M, Chlouverakis G, et al. Primary biliary cirrhosis in a genetically homogeneous population: disease associations 
and familial occurrence rates. BMC Gastroenterol 2012;12:110. doi:10.1186/1471-230X-12-110

14. Parikh-Patel A, Gold EB, Worman H, Krivy KE, Gershwin ME. Risk factors for primary biliary cirrhosis in a cohort of patients from the united states. Hepatology 2001;33:16-21. doi:10.1053/jhep.2001.21165

15. Prince MI, Ducker SJ, James OF. Case-control studies of risk factors for primary biliary cirrhosis in two United Kingdom populations. Gut 2010;59:508-512. doi:10.1136/gut.2009.184218

16. Varyani FK, West J, Card TR. Primary biliary cirrhosis does not increase the risk of UTIs following diagnosis compared to other chronic liver diseases? Liver Int 2013;33:384-388. doi:10.1111/liv.12107

17. Stang A. Critical evaluation of the Newcastle-Ottawa scale for the assessment of the quality of nonrandomized studies in meta-analyses. Eur J Epidemiol 2010;2560:603-5. doi:10.1007/s10654-010-9491-z

18. DerSimonian R, Laird N. Meta-analysis in clinical trials. Control Clin Trials 1986;7:177-188. doi:10.1016/0197-2456(86)90046-2

19. Higgins JP, Thompson SG, Deeks JJ, Altman DG. Measuring inconsistency in meta-analyses. BMJ 2003;327:557-560. doi:10.1136/ bmj.327.7414.557

20. Egger M, Davey Smith G, Schneider M, Minder C. Bias in meta-analysis detected by a simple, graphical test. BMJ 1997;315:629-634. doi:10.1136/ bmj.315.7109.629

21. Bluhm AL, Weinstein J, Sousa JA. Free radicals in tobacco smoke. Nature 1971;229:500

22. Ala A, Stanca CM, Bu-Ghanim M, et al. Increased prevalence of primary biliary cirrhosis near Superfund toxic waste sites. Hepatology 2006;43:525-531. doi:10.1002/hep.21076
23. Arnson Y, Shoenfeld Y, Amital H. Effects of tobacco smoke on immunity, inflammation and autoimmunity. J Autoimmun 2010;34:J258-J265. doi:10.1016/j.jaut.2009.12.003

24. Glossop JR, Dawes PT, Mattey DL. Association between cigarette smoking and release of tumour necrosis factor alpha and its soluble receptors by peripheral blood mononuclear cells in patients with rheumatoid arthritis. Rheumatology (Oxford) 2006;45:1223-1229. doi:10.1093/rheumatology/kel094

25. Juran BD, Lazaridis KN. Environmental factors in primary biliary cirrhosis. Semin Liver Dis 2014;34:265-272. doi:10.1055/s-0034-1383726

26. Qiu F, Liang CL, Liu H, et al. Impacts of cigarette smoking on immune responsiveness: Up and down or upside down? Oncotarget 2017;8:268284. doi:10.18632/oncotarget.13613

27. Harada K, Van de Water J, Leung PS, et al. In situ nucleic acid hybridization of cytokines in primary biliary cirrhosis: predominance of the Th1 subset. Hepatology 1997;25:791-796. doi:10.1002/ hep. 510250402

28. Smyk DS, Rigopoulou EI, Muratori L, Burroughs AK, Bogdanos DP. Smoking as a risk factor for autoimmune liver disease: what we can learn from primary biliary cirrhosis. Ann Hepatol 2012;11:7-14.

29. Reid RD, Pipe AL, Quinlan B. Promoting smoking cessation during hospitalization for coronary artery disease. Can J Cardiol 2006;22:775780. doi:10.1016/S0828-282X(06)70294-X

30. Snaterse M, Scholte Op Reimer WJ, Dobber J, et al. Smoking cessation after an acute coronary syndrome: immediate quitters are successful quitters. Neth Heart J 2015;23:600-607. doi:10.1007/s12471-015-0755-9 


\begin{tabular}{|c|c|c|c|}
\hline Section/topic & $\#$ & Checklist item & $\begin{array}{l}\text { Reported } \\
\text { on page \# }\end{array}$ \\
\hline \multicolumn{4}{|l|}{ TITLE } \\
\hline Title & 1 & Identify the report as a systematic review, meta-analysis, or both. & 1 \\
\hline \multicolumn{4}{|l|}{ ABSTRACT } \\
\hline Structured summary & 2 & $\begin{array}{l}\text { Provide a structured summary including, as applicable: background; objectives; data sources; study eligibility criteria, } \\
\text { participants, and interventions; study appraisal and synthesis methods; results; limitations; conclusions and } \\
\text { implications of key findings; systematic review registration number. }\end{array}$ & 2 \\
\hline \multicolumn{4}{|l|}{ INTRODUCTION } \\
\hline Rationale & 3 & Describe the rationale for the review in the context of what is already known. & 3 \\
\hline Objectives & 4 & $\begin{array}{l}\text { Provide an explicit statement of questions being addressed with reference to participants, interventions, comparisons, } \\
\text { outcomes, and study design (PICOS). }\end{array}$ & 3 \\
\hline \multicolumn{4}{|l|}{ METHODS } \\
\hline Protocol and registration & 5 & $\begin{array}{l}\text { Indicate if a review protocol exists, if and where it can be accessed (e.g., Web address), and, if available, provide } \\
\text { registration information including registration number. }\end{array}$ & $3-4$ \\
\hline Eligibility criteria & 6 & $\begin{array}{l}\text { Specify study characteristics (e.g., PICOS, length of follow-up) and report characteristics (e.g., years considered, } \\
\text { language, publication status) used as criteria for eligibility, giving rationale. }\end{array}$ & $3-4$ \\
\hline Information sources & 7 & $\begin{array}{l}\text { Describe all information sources (e.g., databases with dates of coverage, contact with study authors to identify } \\
\text { additional studies) in the search and date last searched. }\end{array}$ & $3-4$ \\
\hline Search & 8 & $\begin{array}{l}\text { Present full electronic search strategy for at least one database, including any limits used, such that it could be } \\
\text { repeated. }\end{array}$ & $3-4$ \\
\hline Study selection & 9 & $\begin{array}{l}\text { State the process for selecting studies (i.e., screening, eligibility, included in systematic review, and, if applicable, } \\
\text { included in the meta-analysis). }\end{array}$ & $4-5$ \\
\hline Data collection process & 10 & $\begin{array}{l}\text { Describe method of data extraction from reports (e.g., piloted forms, independently, in duplicate) and any processes } \\
\text { for obtaining and confirming data from investigators. }\end{array}$ & $4-5$ \\
\hline Data items & 11 & $\begin{array}{l}\text { List and define all variables for which data were sought (e.g., PICOS, funding sources) and any assumptions and } \\
\text { simplifications made. }\end{array}$ & $4-5$ \\
\hline $\begin{array}{l}\text { Risk of bias in individual } \\
\text { studies }\end{array}$ & 12 & $\begin{array}{l}\text { Describe methods used for assessing risk of bias of individual studies (including specification of whether this was } \\
\text { done at the study or outcome level), and how this information is to be used in any data synthesis. }\end{array}$ & Table 1 \\
\hline Summary measures & 13 & State the principal summary measures (e.g., risk ratio, difference in means). & $5-6$ \\
\hline Synthesis of results & 14 & $\begin{array}{l}\text { Describe the methods of handling data and combining results of studies, if done, including measures of consistency } \\
\left(\text { e.g., }\left.\right|^{2}\right) \text { for each meta-analysis. }\end{array}$ & $5-6$ \\
\hline
\end{tabular}




\section{PRISMA 2009 Checklist}

\begin{tabular}{|c|c|c|c|}
\hline Section/topic & \# & Checklist item & $\begin{array}{l}\text { Reported } \\
\text { on page \# }\end{array}$ \\
\hline Risk of bias across studies & 15 & $\begin{array}{l}\text { Specify any assessment of risk of bias that may affect the cumulative evidence (e.g., publication bias, selective } \\
\text { reporting within studies). }\end{array}$ & $5-6$ \\
\hline Additional analyses & 16 & $\begin{array}{l}\text { Describe methods of additional analyses (e.g., sensitivity or subgroup analyses, meta-regression), if done, indicating } \\
\text { which were pre-specified. }\end{array}$ & $5-6$ \\
\hline \multicolumn{4}{|l|}{ RESULTS } \\
\hline Study selection & 17 & $\begin{array}{l}\text { Give numbers of studies screened, assessed for eligibility, and included in the review, with reasons for exclusions at } \\
\text { each stage, ideally with a flow diagram. }\end{array}$ & 6 \\
\hline Study characteristics & 18 & $\begin{array}{l}\text { For each study, present characteristics for which data were extracted (e.g., study size, PICOS, follow-up period) and } \\
\text { provide the citations. }\end{array}$ & Table 1 \\
\hline Risk of bias within studies & 19 & Present data on risk of bias of each study and, if available, any outcome level assessment (see item 12). & Table 1 \\
\hline Results of individual studies & 20 & $\begin{array}{l}\text { For all outcomes considered (benefits or harms), present, for each study: (a) simple summary data for each } \\
\text { intervention group (b) effect estimates and confidence intervals, ideally with a forest plot. }\end{array}$ & $\begin{array}{l}\text { Figure 2, } \\
3\end{array}$ \\
\hline Synthesis of results & 21 & Present results of each meta-analysis done, including confidence intervals and measures of consistency. & $6-7$ \\
\hline Risk of bias across studies & 22 & Present results of any assessment of risk of bias across studies (see Item 15). & $6-7$ \\
\hline Additional analysis & 23 & Give results of additional analyses, if done (e.g., sensitivity or subgroup analyses, meta-regression [see Item 16]). & 6-7 \\
\hline \multicolumn{4}{|l|}{ DISCUSSION } \\
\hline Summary of evidence & 24 & $\begin{array}{l}\text { Summarize the main findings including the strength of evidence for each main outcome; consider their relevance to } \\
\text { key groups (e.g., healthcare providers, users, and policy makers). }\end{array}$ & $7-8$ \\
\hline Limitations & 25 & $\begin{array}{l}\text { Discuss limitations at study and outcome level (e.g., risk of bias), and at review-level (e.g., incomplete retrieval of } \\
\text { identified research, reporting bias). }\end{array}$ & 8 \\
\hline Conclusions & 26 & Provide a general interpretation of the results in the context of other evidence, and implications for future research. & 8 \\
\hline \multicolumn{4}{|l|}{ FUNDING } \\
\hline Funding & 27 & $\begin{array}{l}\text { Describe sources of funding for the systematic review and other support (e.g., supply of data); role of funders for the } \\
\text { systematic review. }\end{array}$ & 9 \\
\hline
\end{tabular}

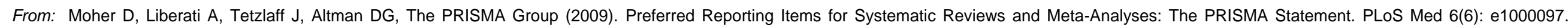
doi:10.1371/journal.pmed1000097 